\title{
Floral Biology of Exotic and Indigenous Almond (Prunus amygdalus Batsch.) Genotypes under Temperate Conditions of Kashmir Valley
}

\author{
Shabeena Majid ${ }^{1 *}$, Amit Kumar ${ }^{2}$, Sabina Naseer ${ }^{1}$, Sabiya Bashir ${ }^{1}$, M. Najeeb Mughal ${ }^{4}$, \\ Z. A. Dar ${ }^{1}$, Asima Amin ${ }^{3}$, Zahida Rashid ${ }^{1}$, Faisal Rasool ${ }^{1}$ and Shafiq Haqeem ${ }^{1}$ \\ ${ }^{1}$ Dryland Agricultural Research Station, ${ }^{3}$ Directorate of extension, ${ }^{4}$ Division of plant \\ pathology, Srinagar, SKUAST-Kashmir, J \& K, India \\ ${ }^{2}$ Division of Fruit Science, SKUAST-Kashmir, Shalimar Campus, Srinagar, J \& K, India \\ *Corresponding author
}

\section{A B S T R A C T}

\begin{tabular}{|l|}
\hline Ke y w o r d s \\
Almond, Floral \\
biology, Bloom, \\
Stigma receptivity, \\
Pollen germination
\end{tabular}

Three exotic and six indigenous almond genotypes were investigated for their floral biology at Dryland Agriculture Research Station, SKUAST-Kashmir for two consecutive years. There was considerable overlapping of bloom among cultivars. Early pink bud $\left(20^{\text {th }}\right.$ February), advanced pink bud ( $5^{\text {th }}$ March), initial bloom ( $8^{\text {th }}$ March) was observed in KD05 whereas full bloom $\left(14^{\text {th }}\right.$ March), initial petal fall $\left(16^{\text {th }}\right.$ March $)$, complete petal fall $\left(18^{\text {th }}\right.$ March). KD-05 was earliest in early pink bud $\left(22^{\text {nd }}\right.$ February), advanced pink bud ( $5^{\text {th }}$ March), initial bloom ( $7^{\text {th }}$ March), full bloom (12 ${ }^{\text {th }}$ March), initial petal fall (15 $5^{\text {th }}$ March) and complete petal fall $\left(19^{\text {th }}\right.$ March) in the second year of study. Primorskij and Pranyaj was late in all the floral phenology characters studied. Duration of bloom ranged from four days in Pranyaj, Mukhdoom, KD-06 and Shalimar to nine days in Primorskij and Merced. Stigma receptivity was 100 per cent on the day of anthesis, one day after and one day before of the anthesis among all the genotypes, however, optimum stigma receptivity was recorded for duration of four days in all the genotypes. Maximum pollen germination of 96.0 per cent and 90.0 per cent was observed for Primorskij and Pranyaj in first and second year of study, respectively. Among all the genotypes studied Mukhdoom, Shalimar, KD03, KD-05 and KD-06 were early bloomers whereas Pranyaj, Merced, Primorskij and Waris were late in flowering.

\section{Introduction}

Almond is one of the major and oldest treenut crops known to the mankind with widespread popularity throughout the world and is mainly grown under rainfed conditions in India with very low productivity (Sharma and Joolka, 2000). Almond is the earliest deciduous fruit and nut tree to bloom in spring, due to its relatively low winter chilling requirement and quick response to warm growing temperatures in the spring (Sutyemez, 2011). The early blooming nature of almond limits its production in many areas and years because of damage from spring frost. Its kernels are delicious and are a concentrated source of energy due to its high oil content. The commercial cultivation of 
almond on marginal lands under non-irrigated conditions could not spread much on account of intrinsic problems like spring frosts and hail storms during the blossoming time. However, still majority of the almond production comes from seedling trees of primitive population grown under rainfed conditions of Kashmir valley with different morphological and biological characteristics. In order to select varieties among these diverse types, characterization and evaluation of these genotypes is indispensable. Most of the commercial almonds cultivars grown throughout the world have been selected by chance from the diverse gene pool of almond seedlings (Kester et al., 1990). In varietal selection of almond the main objective is the introduction of superior seedlings with desirable traits like good growth habit, late bloom, frost and disease resistance, selffertility and high yield. Introduction of few cultivars from abroad and selection released from SKUAST, attempts have been made to evaluate germplasm comprising various almond selections and cultivars so as to assess proper choice of varieties for almond growing belts of Kashmir.

\section{Materials and Methods}

\section{Experimental material and location}

The present investigations on floral biology of almond varieties were conducted at Dryland Agriculture Research Station, (DARS) SKUAST-Kashmir, Jammu and Kashmir. The experimental farm is situated at a latitude of $34^{\circ} 05^{\prime} \mathrm{N}$ and longitude of $74^{\circ} 50^{\prime} \mathrm{E}$ and at an altitude of $1640 \mathrm{~m}$ amsl with temperate region having cold conditions from November to February. The experimental was comprised of nine almond genotypes viz. three exotic (Pranyaj, Merced, Primorskij) and six indigenous (Mukhdoom, Waris, Shalimar, KD-3, KD-5 and KD-6) planted in 1988. Plants of uniform size and vigour were selected randomly and all the trees were kept under similar cultural practices to ensure uniform growth. The experiment was laid out in the randomized block design with four replications for each treatment.

\section{Observation recorded and data analysis}

Observations were recorded on floral phenology of exotic and indigenous genotypes on parameters viz. early pink bud stage (the buds started showing pink color at the tip), advanced pink bud stage (the buds appeared fully pink coloured), initial bloom (10\% of flowers open), final bloom (90\% of flowers open), initial petal fall (10\% flowers showed petal fall), complete petal fall (90\% of flowers showed petal fall). Duration of bloom was calculated by counting the number of days from initial bloom to final bloom. Freshly dehisced pollen grains were dusted on petri dishes having 15 per cent sucrose with agar medium and covered. Pollen tube growth was assessed for each genotype under microscope after $24 \mathrm{hrs}$ of incubation at $22+$ $2^{\circ} \mathrm{C}$. The pollen grains having pollen tube at least two times longer than pollen size were considered to be germinated and expressed in per cent. For stigma receptivity, unopened, about to open buds and opened flowers were examined with the help of magnifying lens to visualize the presence of exudates (watery fluid) on the stigmatic surface indicating stigma to be receptive and expressed in per cent. Data collected on various parameters were statistically analyzed as per the procedure given by Snedecor and Cochran (1994).

\section{Results and Discussion}

Much variation was noticed among all the studied almond varieties for all floral parameters (Table 1). The dates for different floral stages were recorded and it was observed that early pink bud stage was 
commenced in KD-3 and KD-5 i.e. on $20^{\text {th }}$ February in the first year of study and KD-3 i.e. on $21^{\text {st }}$ February in the second year of study closely followed by KD-6 $\left(21^{\text {st }}\right.$ February) and Mukhdoom (21 ${ }^{\text {st }}$ February and $22^{\text {nd }}$ February) in both the year of study and KD-5 ( $22^{\text {nd }}$ February) in the second year of study. The early pink bud stage was noticed late in Primorskij (11 ${ }^{\text {th }}$ March and $12^{\text {th }}$ March) in both the year of study, respectively.

Advanced pink bud stage in both the year was recorded in KD-5 ( $5^{\text {th }}$ March) followed by KD-6 ( $6^{\text {th }}$ March and $7^{\text {th }}$ March), KD-3 ( $8^{\text {th }}$ March and $9^{\text {th }}$ March) and Mukhdoom $\left(8^{\text {th }}\right.$ March) in both the year, respectively however advanced pink bud stage was observed late in Pranyaj (24 $4^{\text {th }}$ March and $23^{\text {rd }}$ March) among all the varieties in both the years.

Initial bloom (10\%) was earlier observed in KD-5 i.e. $8^{\text {th }}$ March and $7^{\text {th }}$ March in both the years, respectively followed by Mukhdoom (10 ${ }^{\text {th }}$ March) and KD-6 (11 ${ }^{\text {th }}$ March) however late initial bloom was commenced in Pranyaj $\left(27^{\text {th }}\right.$ March) in both the years. Early full bloom $(90 \%)$ was recorded in Mukhdoom i.e. $13^{\text {th }}$ March closely followed by KD-5 (14 ${ }^{\text {th }}$ March) and KD-6 (14 ${ }^{\text {th }}$ March) in the first year whereas in the second year early full bloom was observed in KD-5 (12 ${ }^{\text {th }}$ March) closely followed by Mukhdoom (14 ${ }^{\text {th }}$ March) and KD-6 (15 ${ }^{\text {th }}$ March).

Merced ( $31^{\text {st }}$ March and $2^{\text {nd }}$ April) variety was late in full bloom as compared to other varieties in both the years of study. Present findings are in agreement with the earlier findings of Kaskaet al., (2002), Dalalet al., (2004) and Kumar and Ahmad (2015).

Earlier Talaie and Imani (1998) reported flowering time extending upto $31^{\text {st }}$ March to $14^{\text {th }}$ April whereas Kumar and Sharma (2005) observed flowering from $1^{\text {st }}$ February to $3^{\text {rd }}$ week of March which differs from the present study and this might be due to the difference in the environmental conditions of the study area, genetic behaviour of the variety and other cultural operations.

Table.1 Floral phenology of different exotic and indigenous almond genotypes

\begin{tabular}{|c|c|c|c|c|c|c|c|c|c|c|c|c|}
\hline \multirow[t]{2}{*}{ Genotype } & \multicolumn{2}{|c|}{$\begin{array}{c}\text { Early pink } \\
\text { bud }\end{array}$} & \multicolumn{2}{|c|}{$\begin{array}{c}\text { Advanced } \\
\text { pink bud }\end{array}$} & \multicolumn{2}{|c|}{$\begin{array}{l}\text { Initial } \\
\text { bloom } \\
(\mathbf{1 0} \%)\end{array}$} & \multicolumn{2}{|c|}{$\begin{array}{l}\text { Full bloom } \\
\qquad(90 \%)\end{array}$} & \multicolumn{2}{|c|}{$\begin{array}{l}\text { Initial petal } \\
\text { fall }(10 \%)\end{array}$} & \multicolumn{2}{|c|}{$\begin{array}{l}\text { Complete } \\
\text { petal fall } \\
(90 \%)\end{array}$} \\
\hline & $\begin{array}{c}1^{\text {st }} \\
\text { year }\end{array}$ & $\begin{array}{l}2^{\text {nd }} \\
\text { year }\end{array}$ & $\begin{array}{c}1^{\text {st }} \\
\text { year }\end{array}$ & $\begin{array}{l}2^{\text {nd }} \\
\text { year }\end{array}$ & $\begin{array}{c}1^{\text {st }} \\
\text { year }\end{array}$ & $\begin{array}{c}2^{\text {nd }} \\
\text { year }\end{array}$ & $\begin{array}{c}1^{\text {st }} \\
\text { year }\end{array}$ & $\begin{array}{l}2^{\text {nd }} \\
\text { year }\end{array}$ & $\begin{array}{c}1^{\text {st }} \\
\text { year }\end{array}$ & $\begin{array}{l}2^{\text {nd }} \\
\text { year }\end{array}$ & $\begin{array}{c}1^{\mathrm{st}} \\
\text { year }\end{array}$ & $\begin{array}{c}2^{\text {nd }} \\
\text { year }\end{array}$ \\
\hline Pranyaj & $01 / 03$ & $12 / 03$ & $24 / 03$ & $23 / 03$ & $27 / 03$ & $27 / 03$ & $30 / 03$ & $31 / 03$ & 01/04 & $02 / 04$ & 04/04 & $05 / 04$ \\
\hline Merced & $10 / 03$ & $11 / 03$ & $18 / 03$ & $20 / 03$ & $24 / 03$ & $25 / 03$ & $31 / 03$ & $02 / 04$ & $03 / 04$ & $04 / 04$ & $05 / 04$ & 06/04 \\
\hline Primorskij & $11 / 03$ & $12 / 03$ & $17 / 03$ & $18 / 03$ & $23 / 03$ & $24 / 03$ & $31 / 03$ & $01 / 04$ & $02 / 04$ & $04 / 04$ & $05 / 04$ & 06/04 \\
\hline Mukhdoom & $21 / 02$ & $22 / 02$ & $08 / 03$ & 08/03 & $10 / 03$ & $10 / 03$ & $13 / 03$ & $14 / 03$ & $16 / 03$ & $15 / 03$ & $18 / 03$ & $19 / 03$ \\
\hline Waris & $08 / 03$ & $09 / 03$ & $17 / 03$ & $18 / 03$ & $23 / 03$ & $24 / 03$ & $30 / 03$ & $29 / 03$ & $01 / 04$ & $31 / 03$ & 03/04 & $02 / 04$ \\
\hline Shalimar & $28 / 02$ & $27 / 02$ & $11 / 03$ & $12 / 03$ & $12 / 03$ & $14 / 03$ & $16 / 03$ & $17 / 03$ & $20 / 03$ & $19 / 03$ & $25 / 03$ & $23 / 03$ \\
\hline KD-3 & $20 / 02$ & $21 / 02$ & $08 / 03$ & $09 / 03$ & $12 / 03$ & $13 / 03$ & $18 / 03$ & $19 / 03$ & $19 / 03$ & $20 / 03$ & $24 / 03$ & $23 / 03$ \\
\hline KD-5 & $20 / 02$ & $22 / 02$ & $05 / 03$ & $05 / 03$ & $08 / 03$ & $07 / 03$ & $14 / 03$ & $12 / 03$ & $18 / 03$ & $15 / 03$ & $21 / 03$ & $19 / 03$ \\
\hline KD-6 & $21 / 02$ & $22 / 02$ & $06 / 03$ & $07 / 03$ & $11 / 03$ & $11 / 03$ & $14 / 03$ & $15 / 03$ & $16 / 03$ & $17 / 03$ & $19 / 03$ & $20 / 03$ \\
\hline
\end{tabular}


Table.2 Stigma receptivity of different exotic and indigenous almond genotypes

\begin{tabular}{|c|c|c|c|c|c|c|c|c|c|c|}
\hline \multirow[t]{3}{*}{ Genotype } & \multicolumn{10}{|c|}{ Flowers showing stigma receptivity (\%) } \\
\hline & \multicolumn{5}{|c|}{$1^{\text {st }}$ year } & \multicolumn{5}{|c|}{$2^{\text {nd }}$ year } \\
\hline & $\begin{array}{c}-2 \\
\text { days }\end{array}$ & $\begin{array}{c}-1 \\
\text { days }\end{array}$ & $\begin{array}{c}0 \\
\text { days }\end{array}$ & $\begin{array}{c}+1 \\
\text { days }\end{array}$ & $\begin{array}{c}+2 \\
\text { days }\end{array}$ & $\begin{array}{c}-2 \\
\text { days }\end{array}$ & $\begin{array}{c}-1 \\
\text { days }\end{array}$ & $\begin{array}{c}0 \\
\text { days }\end{array}$ & $\begin{array}{c}+1 \\
\text { days }\end{array}$ & $\begin{array}{c}+2 \\
\text { days }\end{array}$ \\
\hline Pranyaj & 46 & 86 & 100 & 100 & 78 & 44 & 88 & 100 & 100 & 77 \\
\hline Merced & 67 & 73 & 100 & 100 & 75 & 64 & 75 & 100 & 100 & 76 \\
\hline Primorskij & 33 & 63 & 100 & 100 & 75 & 34 & 61 & 100 & 100 & 78 \\
\hline Mukhdoom & 33 & 55 & 100 & 100 & 75 & 35 & 52 & 100 & 100 & 76 \\
\hline Waris & 46 & 83 & 100 & 100 & 81 & 43 & 81 & 100 & 100 & 83 \\
\hline Shalimar & 38 & 58 & 100 & 100 & 89 & 40 & 61 & 100 & 100 & 88 \\
\hline KD-3 & 38 & 59 & 100 & 100 & 72 & 39 & 57 & 100 & 100 & 73 \\
\hline KD-5 & 42 & 85 & 100 & 100 & 76 & 39 & 86 & 100 & 100 & 77 \\
\hline KD-6 & 29 & 72 & 100 & 100 & 73 & 31 & 73 & 100 & 100 & 72 \\
\hline $\mathrm{CD}_{0.05}$ & 2.22 & 0.99 & NS & NS & 1.54 & 2.2 & 0.98 & NS & NS & 1.55 \\
\hline
\end{tabular}

(-) Before anthesis

(0)Onanthesis

(+) After anthesis

Fig.1 Duration (days) of bloom in different exotic and indigenous almond genotypes

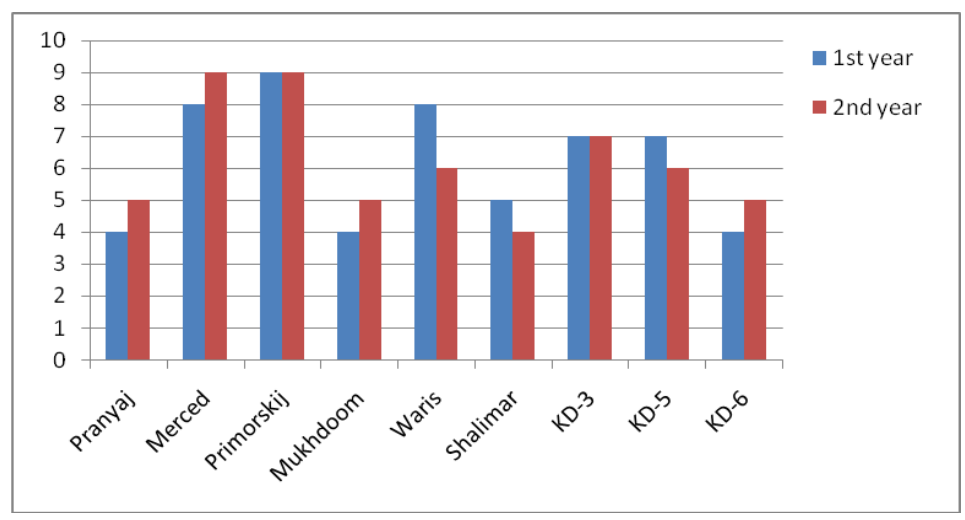

Fig.2 In-vitro pollen germination (\%) of different exotic and indigenous almond genotypes

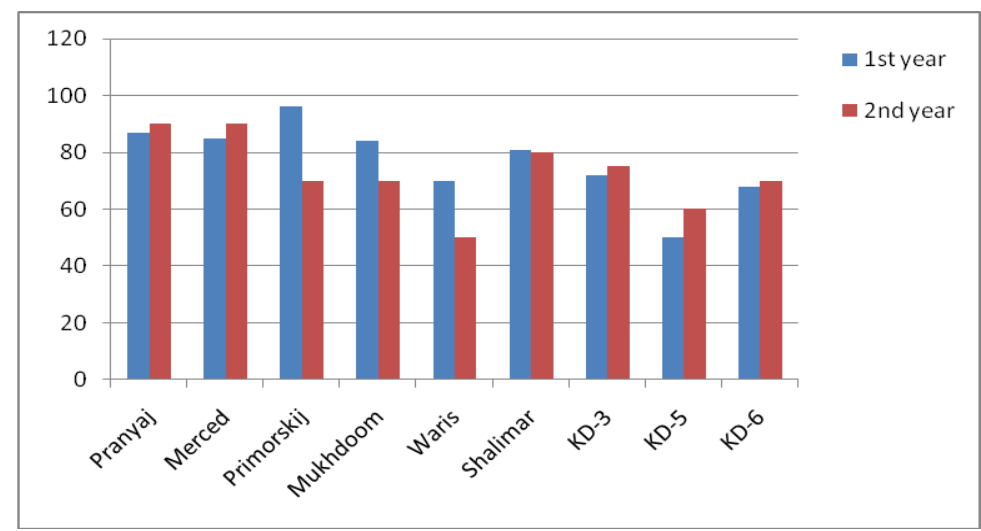


Initial petal fall (10\%) was commenced early in Mukhdoom (16 $6^{\text {th }}$ March and $15^{\text {th }}$ March) and KD-6 (16 ${ }^{\text {th }}$ March and $17^{\text {th }}$ March $)$ in both the year of study, respectively followed by KD-5 (18 ${ }^{\text {th }}$ March and $15^{\text {th }}$ March) whereas Merced $\left(3^{\text {rd }}\right.$ April and $4^{\text {th }}$ April) variety of almond was late to start petal fall $(10 \%)$.

Complete petal fall (90\%) was noticed early in Mukhdoom $\left(18^{\text {th }}\right.$ March) in the first year followed by KD-6 ( $19^{\text {th }}$ March) whereas in the second year complete petal fall was early recorded in Mukhdoom $\left(19^{\text {th }}\right.$ March $)$ and KD5 ( $19^{\text {th }}$ March) closely followed by KD-6 ( $20^{\text {th }}$ March). Merced and Primorskij variety were late in complete petal fall i.e. on $5^{\text {th }}$ April and $6^{\text {th }}$ April in both the year of study, respectively.

In both the year, maximum duration of blooming was observed in Primorskij (9 days) closely followed by Merced and Waris (8 days) in the first year whereas Merced also bloomed for 9 days in the second year (Fig 1). Pranyaj, Mukhdoom and KD-6 bloomed only for 4 days in the first year of study which was least duration as compared to other varieties however minimum duration of blooming in the second year was registered in Shalimar (4 days).Lovicu et al., (2002a) reported 9-12 days and Dalal et al., (2004) reported 4-10 days as effective bloom period in different almond varieties.

Table 2 shows the stigma receptivity of different almond genotypes. The observations obtained indicate that in the first year of study variety Merced $(67.0 \%)$ had highest stigma receptivity two days prior to anthesis which was significantly higher than all other genotypes, however KD-6 showed minimum stigma receptivity $(29.0 \%)$. Pranyaj showed highest stigma receptivity ( $86.0 \%)$ among all the varieties with lowest in Mukhdoom (55.0 $\%$ ) on one day prior to anthesis. On the day of anthesis and one day after anthesis cent per cent stigma receptivity was observed in all the genotypes. After two days of anthesis, Shalimar $(89.0 \%)$ had maximum stigma receptivity and minimum was recorded in KD-3 (72.0\%).

Similar trend of maximum and minimum values for stigma receptivity prior to anthesis and after anthesis in different in different genotypes was observed in second year of study as in the first year. Earlier, Dhillon et al., (1982a) also reported that stigma of almond were receptive one day before and one day after anthesis, the highest being on the day of anthesis in 'California Paper Shell' and 'IXL'. Ortega et al., (2004) and Egea et al., (2004) also observed stigma receptivity upto $48 \mathrm{hrs}$ after anthesis in various almond genotypes.

Significant results were obtained for in-vitro pollen germination in both the years among different almond genotypes and presented in Fig 2. Maximum pollen germination was observed in Primorskij (96.0 \%) in the first year of study which was significantly higher among all the genotypes whereas minimum pollen germination was recorded in KD-5 $(50.0 \%)$.

In the second year, highest in-vitro pollen germination was recorded in Pranyaj and Merced 90.0 per cent which was significantly higher among all the genotypes however minimum pollen germination was recorded in Waris (50.0 \%). Martinez et al., (2000) also reported more than 85.0 per cent invitropollen germination using 15 per cent sucrose and 1.0 per cent agar in two almond cultivars 'Ramillette' and 'Desmayo' while Mussen and Montague (2001) and Das and Kumar (2004) reported 70 - 99 per cent and $50-82$ per cent pollen germination, respectively using 10 per cent sucrose solution for different almond genotypes. 
From the present study, it is concluded that Mukhdoom, Shalimar, KD-03,KD-05 and KD-06 were early bloomers whereas Pranyaj, Merced, Primorskij and Waris were late in flowering. Effective bloom period ranged from four days (Pranyaj, Mukhdoom, KD-06 and Shalimar) to nine days (Primorskij and Merced). Stigma receptivity in all genotypes lasts for four days.

\section{References}

Dalal MA, KD Farooqui, and B Das(2004) Studies on varietal diversity in blooming, productivity and quality characteristics of almond germplasm in Kashmir valley.Acta Hort. 662: 151-155

Das B and K Kumar(2004)In-vivo pollen germination on stigma and pollen tube growth in relation to inter-varietal cross compatibility in almond. Appl. Biol. Res. 6: 44-47.

Dhillon DS, AS Dhatt and RPS Gill (1982a) Pollination studies in almond (Prunus amygdalus Batsch) growing under subtropical conditions. Indian J. Hort.39: 190-195.

Egea J, E Ortega, JA Canovas and F Dicena (2004) Pistil receptivity in selfcompatible almond cultivars.Israel $J$. Plant Sci.52(2): 149-153.

Kaska N, B Yesilkaynah and KU Yilmaz. (2002) Comparison of growth, flowering periods, bloom and small fruit densities of some late flowering Turkish and foreign almond cultivars under irrigated conditions in the Kahraman Maras region. Acta Hort. 591: 465-471.

Kester DE, TM Gradziel and C Grasselly (1990) Almond p.701-758. In: Moore JN and JR JrBallington (eds). Genetic resources of temperature fruit and nut crops. Institute of Horticulture Sciences Wageningin. The Netherlands.
Kumar K and SD Sharma(2005) Selfcompatible indigenous almond selection: characterization and assessment. Acta Hort.696: 65-68.

Kumar D and N Ahmed (2015) Morphological and pomological evaluation of almond (Prunusdulcis) cultivars under North-West Himalayan region of India.Internat.J. Hort.5(15): 1-6

Lovicu G, M Pala,L De-Pau, D Satta and M Farci(2002a) Bio-agronomical behavior of some almond cultivars in Sardinia. Acta Hort.591: 487-491.

Matrinez GP, TM Gradziel, E Ortega and F Dicenta (2000) Short terms storage of almond pollen.HortSci.35(6): 11511152.

Mussen EC and MA Montague (2001) Fungicide impacts on almond pollen germination and tube elongation through pistils. Sci. Hort.87: 15-27.

Ortega E, J Egea and F Dicenta (2004) Effective pollination period in almond cultivars.HortSci.39(1): 19-22.

SharmaMK and NK Joolka(2000) Effect of soil and foliar application of nitrogen on the leaf nutrient status of almond (PrunusamygdalusBatsch.).J. Hort. Sci.29(3/4): 191-192.

Snedecor GW and WG Cochran (1994)Statistical Methods.English edition. First East-West Press edition, New Delhi pp 503

Sutyemez M(2011) Pollen quality and pollen production in some almond cultivars under Kaharamanmaras (Turkey) ecological conditions. African J. Agri. Res.6: 3078-83.

Talaie AR and A Imani (1998) Flowering, pollination and fruit set patterns in some new Iranian almond genotypes. Acta Hort.470: 123-130. 


\section{How to cite this article:}

Shabeena Majid, Amit Kumar, Sabina Naseer, Sabiya Bashir, M. Najeeb Mughal, Z. A. Dar, Asima Amin, Zahida Rashid, Faisal Rasool and Shafiq Haqeem. 2021. Floral Biology of Exotic and Indigenous Almond (Prunus amygdalus Batsch.) Genotypes under Temperate Conditions of Kashmir Valley. Int.J.Curr.Microbiol.App.Sci. 10(01): 2807-2813. doi: https://doi.org/10.20546/ijcmas.2021.1001.325 